\title{
ANALISIS KARAKTERISTIK MORFOMETRI DAN HIDROLOGI SEBAGAI CIRI KARAKTERISTIK BIOGEOFISIK DAS WAI SAMAL KECAMATAN SERAM UTARA TIMUR KOBI KABUPATEN MALUKU TENGAH
}

\author{
Edy Said Ningkeula* \\ Staf Pengajar Fapertahut Uniqbu, e-mail: -
}

\begin{abstract}
ABSTRAK
Tujuan penelitian ini adalah: menganalisis karakteristik (a) karakteristik Morfometri DAS, (b) karakteristik Hidrologi DAS, yang diperlakukan dalam rangka pengembangan sumberdaya alam secara optimal. Penelitian dilakukan di DAS Wai Samal, Kabupaten Maluku Tengah. Secara geografis DAS Wae Samal terletak pada

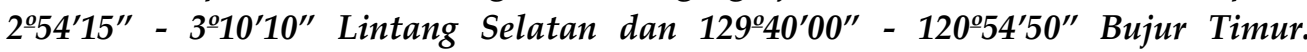
Penelitian telah dilakukan pada bulan Nopember-Desember 2014. Secara umum metoda yang digunakan dalam mengidentifikasi karakteristik DAS Wai Samal Desa Samal Kabupaten Maluku Tengah meliputi: metoda Survei dengan pendekatan deskriptif kuantitatif. Berdasarkan hasil penelitian Analisis Karakteristik Morfometri dan Hidrologi DAS Wai Samal, menunjukkan Karakteristik Mofometri berupa Luas DAS 45.777,36 Ha atau 457,77 $\mathrm{km}^{2}$ tergolong DAS kecil dengan bentuk DAS memanjang dan berbentuk dendritik. Terdapat 5 orde Jaringan Sungai dengan kelas kerapatan sebesar $1,91 \mathrm{~km} / \mathrm{km}^{2}$ tergolong sedang. Karakteristik Hidrologi menunjukkan limpasan permukaan dan debit maksimum sebesar 1435,50 $\mathrm{m}^{3} /$ det buruk dan sering terjadi banjir, namun debit minimum sebesar 17, $101 \mathrm{~m}^{3} /$ det adalah baik, debit rata-rata sebesar 726,30 $\mathrm{m}^{3} /$ det adalah sangat baik. Koefisien Regime Sungai sebesar $83,94 \mathrm{~m}^{3} /$ det adalah tergolong sedang, Koefisien Storage Sungai sebesar 0,024 adalah masih cukup besar.
\end{abstract}

Kata Kunci: Karakteristik Morfometrii Hidrologi DAS.

\section{PENDAHULUAN}

1.1. Latar Belakang

Pengelolaan Daerah Aliran Sungai (DAS) merupakan upaya yang sangat penting sebagai akibat terjadinya penurunan kualitas lingkungan DAS di Indonesia. Hal ini disebabkan oleh pengelolaan sumber daya alam yang tidak ramah lingkungan dan meningkatnya potensi ego sektoral dan ego kewilayahan karena pemanfaatan dan penggunaan sumber daya alam pada DAS, yang melibatkan kepentingan berbagai sektor, dan disiplin ilmu.

Masalah biofisik pada dasarnya merupakan konsekuensi terganggunya DAS berkaitan erat dengan aktifitas manusia yang bersifat merubah tata guna lahan di Daerah
Aliran Sungai (DAS). Perubahan tata guna lahan di kawasan hulu DAS melalui eksploitasi sumber daya hutan, dan di kawasan tengah DAS melalui pengembangan permukiman atau usaha pertanian tanpa mempertimbangkan aspek lingkungan. Semakin meluasnya lahanlahan kritis merupakan gambaran penggunaan lahan yang tidak sesuai dengan peruntukan dan daya dukung lahan, dan tidak disertai dengan upaya penerapan praktek konservasi tanah dan air yang memadai.

Upaya penyelamatan bumi dalam bentuk konservasi tanah dan air, sangat mendesak untuk mengembalikan ekosistem tanah dan air demi keselamatan kehidupan yang menyertainya serta keberlanjutan (sustainability) DAS. Konservasi tanah dan air 
adalah dua hal yang saling berkaitan. Tindakan konservasi/perlindungan alam terhadap tanah, berdampak pada ketersediaan kuantitas dan kualitas air yang berkelanjutan. Usaha konservasi/perlindungan alam terhadap air, akan melibatkan suatu tindakan untuk pengelolaan daerah tangkapan air secara terpadu, yang berarti juga tindakan konservasi tanah (Sinukaban., 2007).

Pada perumusan Lokakarya Pengelolaan DAS yang diadakan di Yogyakarta pada bulan Oktober 1985 telah disepakati bahwa Pengelolaan DAS dilakukan sesuai dengan azas "One Watershed One Management Plan" yang sekarang lebih dikenal lagi dengan "One Watershed One River One Management". Dari pernyataan azas tersebut mempunyai pengertian bahwa satuan DAS telah ditetapkan sebagai satuan (unit) pengelolaan dan penanganan yang berbeda antara satuan DAS satu dengan satuan DAS yang lain sesuai dengan karakteristik DAS.

Dalam sepuluh tahun terakhir potensi DAS di seluruh Indonesia termasuk di Maluku semakin menurun. Menurunnya kondisi DAS ditandai dengan terjadinya bencana banjir dan longsor di musim hujan dan kekeringan di musim kemarau. Penyebab terjadianya penurunan kualitas DAS adalah hasil interaksi antara faktor iklim (terutama curah hujan), kondisi geomorfologi (geologi, tanah dan topografi) dan terutama adalah aktivitas manusia yang menyebabkan penurunan kualitas (degradasi) sumberdaya hutan dan lahan berupa lahan kritis. Luas lahan kritis di Maluku pada tahun 2011 mencapai 762.324 ha, meningkat 24,52\% dibanding tahun 2006 (612.219 ha). Untuk menghijaukan lahan kritis di Provinsi Maluku, berbagai upaya rehabilitasi hutan dan lahan baik di dalam kawasan maupun diluar kawasan hutan terus dilakukan, antara lain kegiatan reboisasi dan penghijauan (Direktorat Jenderal Bina Pengelolaan DAS dan Perhutanan Sosial, 2013).

Berdasarkan uraian di atas maka dirasa perlu dilakukan suatu penelitian mengenai : "Analisis Karakteristik Morfometri dan Hidrologi Sebagai Ciri Karakteristik Biogeofisik DAS Wai Samal".

\subsection{Tujuan Penelitian}

Tujuan penelitian ini adalah: Menganalisis karakteristik (a) karakteristik Morfometri DAS, (b) karakteristik Hidrologi DAS, yang diperlakukan dalam rangka pengembangan sumberdaya alam secara optimal.

\section{I.3. Manfaat Penelitian}

Hasil dari penelitian ini diharapkan dapat: Menyediakan data dan informasi akurat tentang karakteristik DAS Wai Samal, mengenai sifat dan ciri/watak yang khas dalam biogeofisik DAS. dalam rangka pengelolaan DAS berkelanjutan.

\section{BAHAN DAN METODE PENELITIAN}

\subsection{Tempat dan Waktu Penelitian}

Penelitian dilakukan di DAS Wai Samal, Kabupaten Maluku Tengah. Secara geografis DAS Wae Samal terletak pada $2^{\circ} 54^{\prime} 15^{\prime \prime}$ 3010'10" Lintang Selatan dan 129\%40'00" $120^{\circ} 54^{\prime} 50^{\prime \prime}$ Bujur Timur. Penelitian telah dilakukan pada bulan November - Desember 2014, melalui survei lapangan dan analisis laboratorium serta analisis data.

\subsection{Bahan dan Alat}

Bahan yang digunakan dalam penelitian ini adalah: Peta Citra Satelit P. Seram, Peta topografi P. Seram, Peta Geologi P. Seram, Peta kerja lapang skala 1:50.000, Blangko Pengisian

Alat yang digunakan dalam penelitian ini adalah: GPS, Kompas, Altimeter, Stopwatch, Abney level, Kamera, Perangkat komputer, Scanner HP, Printer HP, Software ArcView 33 dan ArcGis 9., Set sampel air.

\subsection{Teknik Pengumpulan Data}

\subsubsection{Metoda Identifikasi}

Secara umum metoda yang digunakan dalam mengidentifikasi karakteristik DAS Wai Samal Desa Samal Kabupaten Maluku Tengah meliputi: metoda Survei dengan pendekatan deskriptif kuantitatif.

\subsubsection{Pengumpulan Data}

Kegiatan ident ifikasi ini menyangkut karakteristik Biogeofisik DAS sehingga dilakukan dengan menggunakan data yang telah ada (data sekunder) dan dilengkapi dengan data primer yang dirasakan masih kurang dalam rangka mendukung analisis 
pemahaman dan pengetahuan mengenai karakteristik DAS yang teliti. Seleksi data dilakukan mengingat data yang diperoleh sangat bervariasi, terutama mengenai formatnya, baik dalam DAS yang berbeda maupun dalam DAS yang sama.

Data yang dikumpulkan meliputi :

1. Karakteristik Morfometri DAS, yang meliputi :
a. Luas DAS
b. Bentuk DAS
c. Jaringan Sungai
d. Pola Aliran Sungai
e. Kerapatan Aliran Sungai
f. Profil Sungai Utama

2. Karakteristik Hidrologi DAS, yang meliputi :
a. Limpasan Permukaan
b. Debit Maksimum (Qmaks)
c. Debit Minimum (Qmin)

d. Debit Rata-Rata (Qav)

e. Koefisien Regime Sungai (Qmaks/Qmin)

f. Kofisien Storage Sungai (Qmin/Qav)

\subsection{Pengolahan Data dan Analisis Data}

\subsubsection{Penetapan Kriteria}

a. Karakteristik Morfometri DAS

1. Luas DAS

Cara menghitung luas DAS yaitu dengan beberapa metode atau cara yaitu : 1) Menghitung luas DAS dengan cara menampilkan pada kertas millimeter grafis (grid berukuran $1 \mathrm{~cm} \times 1 \mathrm{~cm}$ ). Luas DAS adalah jumlah kotak tercakup, dikalikan unit kotak, kemudian dikalikan skala peta. 2) Menggunakan Planimeter 3) Menggunakan Sistem Informasi Geografis.

Kriteria atau klasiikasi Luas DAS yang dapat membagi beberapa luas dAS di Dunia ini, seperti terlihat pada Tabel 1.

Tabel 1. Klasifikasi Berdasarkan Luas DAS

\begin{tabular}{ccc}
\hline No & Luas DAS (ha) & Klasifikasi DAS \\
\hline 1. & 1.500 .000 ke atas & DAS Sangat Besar \\
2. & $500.000-<1.500 .000$ & DAS Besar \\
3. & $100.000-<500.000$ & DAS Sedang \\
4. & $10.000-<100.000$ & DAS Kecil \\
5. & $<10.000$ & DAS Sangat Kecil \\
\hline
\end{tabular}

Sumber : Peraturan Direktorat Jenderal Bina Pengelolaan DAS dan Perhutanan Sosial (2013)

\section{Bentuk DAS}

Miller (1953) dalam Kemenhut (2013) menggunakan circularity ratio dengan menggunakan rumus (1) di bawah ini :

$$
R_{c}=\frac{4 \pi A}{p^{2}}
$$

Dimana :

Rc = nisbah kebulatan (faktor bentuk kebulatan)

$A=$ luas DAS $\left(\mathbf{k m}^{2}\right)$

$\mathbf{P}=$ keliling (perimeter DAS) $(\mathbf{k m})$

$\pi=$ konstanta sebesar 3,14 (22/7).

Bila besarnya nilai Rc adalah 1 berarti bentuk DAS tersebut adalah lingkaran.

\section{Jaringan Sungai

Metode

kuantitatif

untuk mengklasifikasikan sungai dalam DAS adalah pemberian orde sungai maupun cabangcabang sungai secara sistematis seperti berikut ini :1) Sungai-sungai pada daerah hulu mendapat skala terkecil (1). 2) Pertemuan sungai dengan orde sama, maka terjadi kenaikan orde. 3) Pertemuan sungai dengan orde yang berbeda tidak terjadi kenaikan orde. Dari hasil jumlah alur pada masing-masing orde sungai, maka selanjutnya dihitung indeks percabangan sungai dan untuk indeks percabangan rerata tertimbang. Setelah itu dipadukan dengan kriteria tingkat percabangan sungai yang dikemukakan oleh; (Rahayu dkk, 2009 dalam Talakua S.M., 2009), seperti disajikan pada Tabel 2. 
Tabel 2. Klasifikasi Indeks Tingkat Percabangan Sungai

\begin{tabular}{|c|c|}
\hline $\begin{array}{c}\text { Indeks Tingkat } \\
\text { Percabangan Sungai }\end{array}$ & Uraian \\
\hline $\mathbf{R b}<3$ & $\begin{array}{l}\text { alur sungai mempunyai kenaikan muka air banjir dengan } \\
\text { cepat, sedangkan penurunannya berjalan lambat }\end{array}$ \\
\hline Rb 3 - 5 & $\begin{array}{l}\text { alur sungai mempunyai kenaikan dan penurunan muka } \\
\text { air banjir tidak terlalu cepat atau tidak terlalu lambat } \\
\text { alur sungai mempunyai kenaikan muka air banjir dengan }\end{array}$ \\
\hline $\mathrm{Rb}>5$ & $\begin{array}{l}\text { cepat, demikian pula penurunannya akan berjalan } \\
\text { dengan cepat }\end{array}$ \\
\hline
\end{tabular}

4. Kerapatan Aliran

Linsley (1975) dalam Peraturan Direktorat

Kerapatan aliran dapat dinyatakan Jenderal Bina Pengelolaan DAS dan dengan rumus (2) di bawah ini : Perhutanan Sosial (2013), menyatakan bahwa jika nilai kepadatan aliran lebih kecil dari 1

$$
\operatorname{Dd}=\sum L_{n} / A
$$
mile/ mile ${ }^{2}\left(0,62 \mathrm{Km} / \mathrm{Km}^{2}\right)$, DAS akan mengalami penggenangan, sedangkan jika nilai kerapatan aliran lebih besar dari 5 mile/ mile $^{2}$ ( Dimana :

$$
\begin{aligned}
& \text { Dd }=\text { kerapatan aliran }\left(\mathbf{k m} / \mathbf{k m}^{2}\right) \\
& \text { Ln }=\text { panjang sungai }(\mathbf{k m}) \\
& A=\text { luas DAS }\left(\mathbf{k m}^{2}\right) .
\end{aligned}
$$

$3,10 \mathrm{Km} / \mathrm{Km}^{2}$ ), DAS sering mengalami kekeringan.

Kriteria indeks kepadatan drainase atau indeks kerapatan aliran sungai $\left(\mathrm{km} / \mathrm{Km}^{2}\right)$ dapat terlihat pada Tabel 3.

Tabel 3. Kriteria Indeks Kepadatan Drainase

\begin{tabular}{ccc}
\hline No. & Indeks Kerapatan Aliran Sungai $\left(\mathrm{km} / \mathrm{km}^{2}\right)$ & Kriteria \\
\hline 1. & $<0,25$ & Rendah \\
2. & $0,25-10$ & Sedang \\
3. & $10-25$ & Tinggi \\
4. & $>25$ & Sangat Tinggi \\
\hline
\end{tabular}

Sumber : Kementerian Kehutanan RI, (2010).

5. Pola Sungai Utama

a. Penentuan Sungai Utama

Cara menentukan sungai utama menurut Horton dalam Peraturan Direktorat Jenderal Bina Pengelolaan DAS dan Perhutanan Sosial (2013), adalah dengan memperhatikan pertemuan antara 2 (dua) sungai, selanjutnya :

a. Apabila sudut sama $(\phi 1=\phi 2)$, maka pilihlah sungai yang lebih panjang

b. Apabila sudut tidak sama, maka pilihlah sudut yang kecil (misal $\theta 4>\theta 3$, pilih sungai pada sudut $\theta 3$ )

a.1. Panjang Sungai Utama dan Sungai Terpanjang

Panjang sungai terpanjang dalam DAS diukur dari outlet ke sumber asal air.

a.2. Perbedaan Tinggi DAS

Ketinggian suatu tempat dapat diketahui dari peta topografi, diukur di lapangan atau melalui foto udara, jika terdapat salah satu titik kontrol sebagai titik ikat. Hubungan antara elevasi dengan luas DAS dapat dinyatakan dalam bentuk hipsometrik (Hypsometric Curve).

\section{a.3.Gradien Sungai Utama}

Salah satu cara menghitung gradien sungai rata - rata adalah dengan slope faktor yang dikembangkan oleh Benson (1962) dalam Peraturan Direktorat Jenderal Bina Pengelolaan DAS dan Perhutanan Sosial (2013) yaitu dengan menghitung lereng saluran antara $10 \%$ dan 85 $\%$ jarak dari outlet, seperti pada rumus berikut ini.

Gradien Sungai $(\mathrm{Su})=(\mathrm{H} 85-\mathrm{H} 10) /(0,75) \mathrm{Lb}$

Dimana : $\mathrm{H}$ adalah ketingian dan $\mathrm{Lb}$ adalah panjang sungai utama. 


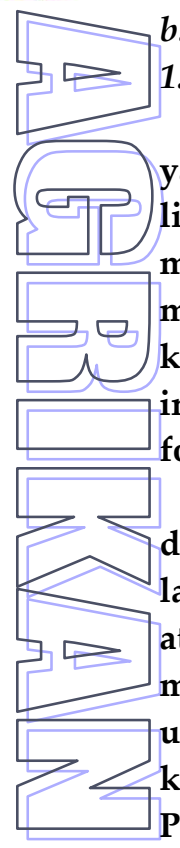

b. Karakteristik Hidrologi DAS

1. Limpasan Permukaan

Estimasi besarnya limpasan permukaan yang dinyatakan dalam bentuk koefisien limpasan permukaan dapat dilakukan dengan mendasarkan pada parameter-parameter morfometri dan morfologi yang menjadi karakteristik DAS yang diperoleh melalui interpretasi citra penginderaan jauh (satelit dan foto udara) dan analisis peta-peta tematik.

Limpasan permukaan bergerak pada atau diatas permukaan lahan pada setiap jengkal lahan (space of land), maka wilayah DAS ataupun Sub DAS harus dibagi-bagi lagi menjadi satuan-satuan (unit) lahan terkecil untuk menilai besarnya nilai atau angka koefisien setiap satuan-satuan lahan tersebut. Penjumlahan nilai ataupun angka koefisien limpasan permukaan dari setiap satuan-satuan lahan dalam suatu DAS ataupun Sub DAS dapat digunakan untuk menyatakan besarnya nilai atau angka koefisien limpasan permukaan DAS ataupun Sub DAS yang bersangkutan.

2. Debit Maksimum (Qmaks)

Perhitungan debit maksimum (Qmaks)

dapat dihitung dengan menggunakan Rumus

Rasional (3) sebagai berikut.

$$
\text { Qmaks = C. I. A }
$$

Dimana :

Qmaks = Debit maksimum (banjir puncak) (m³/detik),

C = Koefisien limpasan permukaan, besarnya 0,278 untuk luas DAS/Sub-DAS $\left(\mathrm{km}^{2}\right)$, dan 0,00278 untuk luas DAS/Sub-DAS (ha),

I = Intensitas hujan yang lamanya sama dengan waktu konsentrasi (Tc) (mm/hari),

A = Luas DAS $\left(\mathrm{km}^{2}\right.$ atau ha tergantung koefisien $\mathrm{C}$ ).

Keterangan : Rumus Metode Rasional hanya dapat digunakan untuk Sub-DAS kecil di Pulau Jawa ( $<5.000$ hektar) (Gunawan, 2012) atau (<6.000 hektar) (Hadi, 2005) atau DAS/Sub DAS kecil di luar Pulau Jawa $(<10.000$ hektar) (PEPDAS, 2010).

Perhitungan Debit maksimum (banjir puncak) di Lapangan (Qmaks) dapat dilakukan di mulut sungai pada DAS atau Sub-DAS, dengan menggunakan Rumus Manning.
Pengukuran debit maksimum (Qmaks) dengan Rumus atau Metode Manning untuk digunakan sebagai pembanding hasil pengukuran debit maksimum dengan menggunakan Rumus atau Metode Rasional. Pengukuran debit maksimum (Qmaks) dengan menggunakan Metode Manning dilakukan pada suatu penampang sungai pada mulut DAS atau Sub-DAS. Adapun rumus yang digunakan dapat dinyatakan sebagai rumus (4) berikut ini.

Qmaks $=1 / n \cdot R^{2 / 3} \cdot S^{1 / 2} \cdot A$

\section{Dimana :}

Qmaks = Debit maksimum (banjir puncak) (m³/detik),

R = Jari-jari hidrolis penampang sungai (m),

S = Kemiringan hidrolis muka air sungai pada saat banjir maksimum terjadi denga melihat tanda-tanda pada saat terjadi banjir maksimum (\%),

A = Luas penampang sungai $\left(\mathrm{m}^{2}\right)$,

$\mathrm{N}=$ Koefisien kekasaran dasar sungai rata-rata dengan pembobotan,

Keterangan : $\mathbf{R}=\mathrm{A} / \mathrm{p}$ (p: perimeter basah penampang sungai).

3. Debit Minimum (Qmin)

Pengukuran debit sungai terkecil (debit minimum) atau debit sungai saat ini pada saat tidak terjadi banjir dapat dirumuskan sesuai dengan rumus (5) berikut ini.

$$
Q \min =w \cdot d \cdot a \cdot 1 / t
$$

Dimana :

Qmin = Debit sungai minimum (m³/detik),

$\mathrm{w} \quad=$ Lebar penampang sungai rata-rata (m), d = Kedalaman air sungai ratarata $(\mathrm{m})$,

a = Koefisien kekasaran dasar penampang sungai rata-rata $(\%)$,

$1 / t=$ Kecepatan aliran pada seksi sungai rata-rata (m/detik).

Keterangan: seyogyanya setiap pengukuran parameter sungai dilakukan minimal 3 kali perlakuan. Pengukuran debit banjir maksimum (Qmaks) dapat dilakukan pada saat musim kemarau dengan melihat tanda-tanda banjir puncak pada tepi 
penampang sungai atau menanyakan kepada Ð penduduk setempat (lokal). Demikian juga pengukuran debit minimum dipilih dalam kondisi debit sungai paling kecil pada saat musim kemarau. Pada dasarnya debit minimum suatu sungai tidak pernah sama dengan nol (Qmin tidak 0) karena sebelum air sungai itu mengalir hingga mulut sungai biasanya di bagian hulu DAS air sungai telah dimanfaatkan oleh penduduk petani untuk irigasi tradisional. Oleh karena itu perlu dilakukan penelusuran di lapangan (river routing) guna mengetahui adanya pengambilan air sungai di bagian hulu oleh penduduk petani. Pengukuran debit irigasi dilakukan dengan menggunakan metode pengukuran debit minimum atau Metode Larutan Garam (Solution method).

4. Debit Rata-Rata (Qav)

Merupakan rataan dari Debit Maksimum dan Debit Minimum air sungai.

5. Koefisien Regime Sungai (Qmaks/Qmin)

Parameter karakteristik Hidrologi DAS yang diperoleh dari perbandingan antara debit maksimum (Qmaks) dan debit minimum (Qmin). Apabila nilai besaran perbandingan antara Qmaks/Qmin besar (>50) berarti lebih banyak kejadian banjir maksimum yang terjadi, dan sebaliknya kejadian debit minimum dapat sangat-sangat kecil hanya tidak pernah nol (0).

6. Koefisien Penyimpanan/Storage Sungai (Qmin/Qav)

Parameter karakteristik hidrologi DAS yang diperoleh dari perbandingan antara debit minimum (Qmin) dan debit rata-rata (Qav) atau sering disingkat dengan parameter Qmin/Qav.

\subsubsection{Pengolahan Data (Pemetaan)}

Pemetaan Data fisik DAS (luas das, bentuk das, Jaringan Sungai, Pola Aliran Sungai, Kerapatan Aliran Sungai, Profil Sungai Utama, Limpasan Permukaan, Debit Maksimum (Qmaks), Debit Minimum (Qmin), Debit Rata-Rata (Qav), Koefisien Regime Sungai (Qmaks/Qmin), Kofisien Storage Sungai (Qmin/Qav).

\section{HASIL DAN PEMBAHASAN}

\subsection{Karakteristik Morfometri DAS}

Karakteristik Morfometri pada DAS Wai Samal dianalisis berdasarkan data luas DAS, bentuk DAS, jaringan sungai, pola aliran sungai, kerapatan aliran dan profil sungai utama.

\section{a. Luas DAS}

Dengan menggunakan Sistem Informasi Geografis berupa ArcVieu 33 dan ArcGis 93 didapatkan luas DAS Wai Samal adalah $45.777,36 \mathrm{Ha}$ atau $457,77 \mathrm{~km}^{2}$, dan sesuai dengan kriteria luas DAS, maka DAS Wai Samal termasuk DAS kecil dengan kisaran luas DAS $10.000-<100.000 \mathrm{Ha}$.

Ukuran luas DAS Wai Samal yang tergolong kecil namun menunjukkan bahwa DAS ini memiliki suatu luasan wilayah yang dapat menampung dan menyimpan air hujan (presipitasi), kemudian mengalirkannya melalui saluran-saluran drainase alami seperti sungai dengan anak-anak sungai (Wai kobi, Wai Musi, Wai Asih, Wai tonipa) menuju ke laut. Dengan demikian berperan sebagai wilayah bentang lahan dan wilayah ekosistim serta suatu wilayah kesatuan hidrologis dengan fungsi pengaturan tata air wilayah.

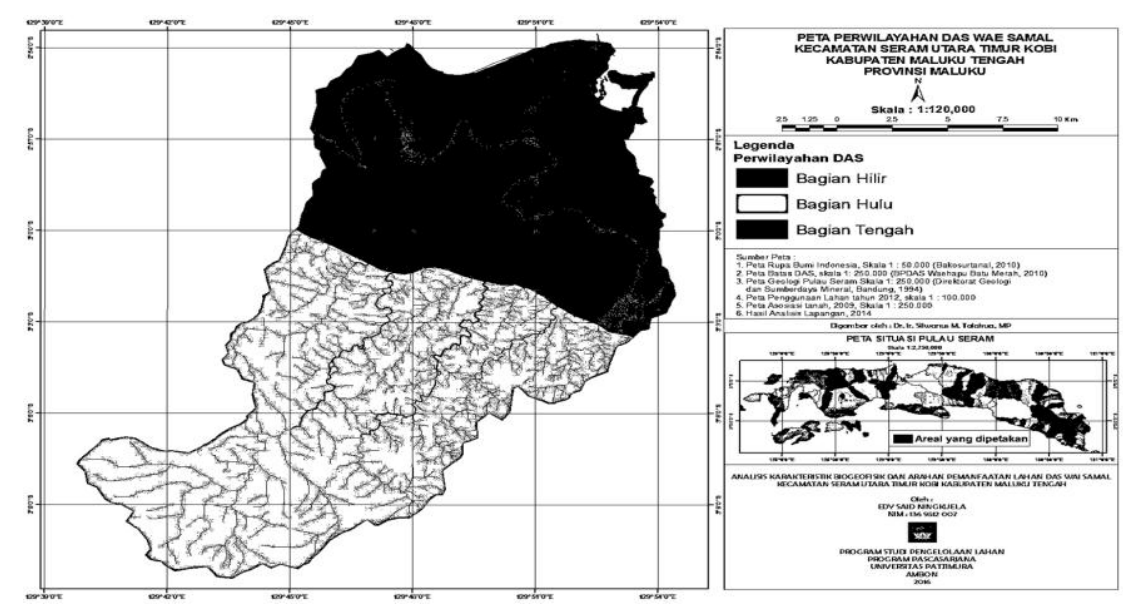

Gambar 1. Peta Perwilayahan DAS Wai Samal 


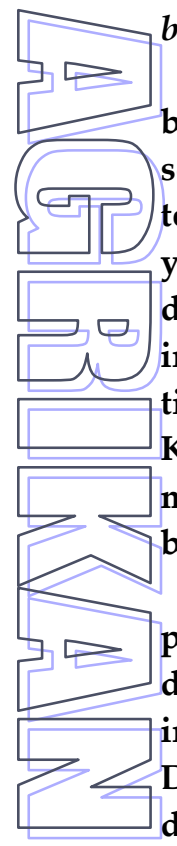

b. Bentuk DAS

Bentuk DAS Wai Samal adalah termasuk bentuk yang dendritik, agak memanjang seperti percabangan pohon, percabangan tidak teratur dengan arah dan sudut yang beragam, yang merupakan perakitan anak-anak sungai dengan sungai utama. Pada pola aliran seperti ini, umumnya terjadi peningkatan aliran pada titik pertemuan anak-anak sungai yaitu Wai Kobi, Wai Musi dan Wai Asih dan mengkonsentrasi ke satu titik serta bersatu di bagian hilir berupa Wai Samal.

Bentuk DAS mempunyai pengaruh pada pola aliran sungai dan ketajaman puncak discharge banjir. Bentuk daerah aliran sungai ini sulit untuk dinyatakan secara kuantitatif. Dengan membandingkan konfigurasi basin, dapat dibuat suatu indeks yang didasarkan pada derajat kekasaran atau circularity dari DAS. Perhitungan Nisbah Kebulatan DAS Wai Samal : Diketahui : $\mathbf{A}=$ Luas DAS $\left(\mathrm{km}^{2}\right)=$ $45.777,36 \mathrm{Ha}$ atau $457,77 \mathrm{~km}^{2} ; \mathrm{Lb}=$ Panjang sungai utama $(\mathrm{km})=30.35 \mathrm{~km} ; \mathrm{P}=$ Keliling DAS $(\mathrm{km})=122,72 \mathrm{~km}$, dengan $\mathrm{Rc}=0,387$. Perhitungan Nisbah Memanjang DAS : Diketahui : A = luas DAS $\left(\mathrm{km}^{2}\right)=457,77 \mathrm{~km}^{2} ; \mathrm{Lb}$ $=$ panjang sungai utama $(\mathrm{km})=35,30 \mathrm{~km}$, dengan $\operatorname{Re}=0,70$.
Hal ini memberi gambaran bahwa DAS tersebut memiliki nisbah kebulatan yang rendah dan tidak berbentuk lingkaran, ternyata bahwa nisbah memanjang DAS atau faktor bentuk memanjang DAS adalah sebesar 0.70, yang mengindikasikan bahwa bentuk DAS ini termasuk dalam kategori lonjong atau memanjang. Ini memberi gambaran adanya waktu konsentrasi yang diperlukan semakin lama sehingga fluktuasi banjir semakin rendah (Rahayu dkk, 2009 dalam Talakua S.M., 2009).

\section{c. Jaringan Sungai}

Metode kuantitatif untuk mengklasifikasikan sungai dalam DAS adalah pemberian orde sungai maupun cabang-cabang sungai secara sistematis seperti dengan menggunakan ArcView 33, didapatkan orde DAS Wai Samal sebanyak 5 (lima) dan dapat digambarkan pada Tabel 4.

Pola aliran atau susunan sungai pada suatu DAS merupakan karakteristik fisik setiap drainase basin yang penting karena pola aliran sungai mempengaruhi efisiensi sistem drainase serta karakteristik hidrografis dan pola aliran menentukan bagi pengelola DAS untuk mengetahui kondisi tanah dan permukaan DAS khususnya tenaga erosi.

Tabel 4. Orde Sungai DAS Wai Samal

\begin{tabular}{ccc}
\hline $\begin{array}{c}\text { Orde } \\
\text { Sungai }\end{array}$ & Panjang $(\mathrm{km})$ & Jumlah \\
\hline 1 & 493,30 & 701 \\
2 & 155,88 & 150 \\
3 & 122,08 & 30 \\
4 & 65,76 & 16 \\
5 & 35,30 & 1 \\
\hline Total & 872,32 & 898 \\
\hline Sumber: Hasil Penelitian dan Analisis, (2014)
\end{tabular}

Dari hasil jumlah alur pada masingmasing orde sungai, maka selanjutnya dihitung indeks percabangan sungai yaitu :

$\mathrm{Rb}$ pada orde $1=701 / 150=4,67$

$R b$ pada orde $2=150 / 30=5,00$

$\mathrm{Rb}$ pada orde $3=30 / 16=1,88$

$R b$ pada orde $4=16 / 1=16$

Selanjutnya untuk indeks percabangan rerata tertimbang dihitung sebagai berikut :

$\mathrm{WRb}$ pada orde $1=(4,67)(701+150) / 701=$ 5,67
WRb pada orde $2=(5,00)(150+30) / 150=$ 6,00

$\mathrm{WRb}$ pada orde $3=(1,88)(30+16) / 30=2,88$

WRb pada orde $4=(16,00)(16+1) / 16=17$

Jadi indeks percabangan rerata tertimbang $(\mathrm{WRb})$ didapat dari :

$\mathrm{WRb}$ rerata $=(\mathrm{WRb} 1+\mathrm{WRb} 2+\mathrm{WRb} 3+$ WRb4)/4

$$
\begin{aligned}
& =(5,67+6,00+2,88+17,00) / 4 \\
& =7,89
\end{aligned}
$$


Berdasarkan hasil perhitungan di atas dan setelah dipadukan dengan kriteria tingkat percabangan sungai yang dikemukakan oleh; (Rahayu S, Widodo RH, van Noordwijk $M$, Suryadi I dan Verbist B, 2009), menunjukkan bahwa indeks tingkat percabangan sungai DAS Wai Samal sebesar 7,89 berada pada kisaran $\mathbf{R b}$ 5, yang memberikan makna bahwa alur sungai mempunyai kenaikan muka air banjir dengan cepat, demikian pula penurunannya akan berjalan dengan cepat.

\section{d. Pola aliran Sungai}

Pola aliran atau susunan sungai pada suatu DAS merupakan karakteristik fisik setiap drainase basin yang penting karena pola aliran sungai mempengaruhi efisiensi sistem drainase serta karakteristik hidrografis dan pola aliran menentukan bagi pengelola DAS untuk mengetahui kondisi tanah dan permukaan DAS khususnya tenaga erosi.

Pola aliran DAS Wai Samal adalah Dendritik, umumnya terjadi peningkatan aliran pada titik pertemuan anak-anak sungai. Berkembang di batuan yang homogeny dan tidak terkontrol oleh struktur, umunya pada batuan sedimen dengan perlapisan horisontal, atau pada batuan beku dan batuan kristalin yang homogen.

\section{e. Kerapatan Aliran}

Kerapatan aliran adalah panjang aliran sungai per kilometer persegi luas DAS. Semakin besar nilai Dd semakin baik sistem pengaliran (drainase) di daerah tersebut. Artinya, semakin besar jumlah air larian total (semakin kecil infiltrasi) dan semakin kecil air tanah yang tersimpan di daerah tersebut.

Dari hasil analisis dengan ArcGIS 93, didapat bahwa : $\mathrm{L}=$ panjang aliran total DAS Wai Samal adalah $872,32 \mathrm{~km}, \mathrm{~A}=$ total luas DAS Wai Samal berdasarkan pengukuran planimetris adalah 45777,36 ha atau $457,77 \mathrm{~km}^{2}$. $\mathrm{Dd}=1,91 \mathrm{~km} / \mathrm{km}^{2}$. Maka kepadatan daerah aliran sungai Wai Samal adalah sebesar 1,91 $\mathbf{k m} / \mathbf{k m}^{2}$. Berdasarkan kriteria Kementerian Kehutanan (2010), maka kapadatan sungai DAS Wai Samal, tergolong dalam kelas kerapatan sedang, yang mengindikasikan banyak air yang dapat tertampung di badan-badan sungai tergolong sedang.

\section{f. Profil Sungai Utama}

1. Panjang Sungai Utama dan Sungai Terpanjang Penentuan sungai utama menurut Horton dalam Peraturan Direktorat Jenderal Bina Pengelolaan DAS dan Perhutanan Sosial (2013), adalah dengan memperhatikan pertemuan antara 2 (dua) sungai.

Sungai merupakan jalan air alami, yang mengalir menuju samudera, danau, laut dan atau ke sungai yang lain. Sungai terdiri dari beberapa bagian, bermula dari mata air yang mengalir ke anak sungai, kemudian beberapa anak sungai akan bergabung untuk membentuk sungai utama.

Berdasarkan hasil pengukuran planimetris maupun program ArcView 33, maka didapatkan panjang sungai utama pada DAS Wai Samal adalah $35,30 \mathrm{~km}$, dan panjang sungai terpanjang adalah $56,44 \mathrm{~km}$, seperti disajikan pada Gambar 2. dan Gambar 3.

Perbedaan Tinggi DAS

Elevasi rata-rata dan variasi ketinggian pada suatu DAS merupakan faktor penting yang berpengaruh terhadap temperatur dan pola hujan, khususnya pada daerah-daerah dengan topografi bergunung. Ketinggian suatu tempat dapat diketahui dari peta topografi, diukur dilapangan atau melalui foto udara, jika terdapat salah satu titik kontrol sebagai titik ikat. Hubungan antara elevasi dengan luas DAS dapat dinyatakan dalam bentuk hipsometrik (Hypsometric Curve ).

Hasil analisis dengan menggunakan ArcGIS serta merujuk Kurva Hipsometrik suatu DAS (AVERY, 1975), menunjukkan bahwa perbedaan tinggi di DAS Wai Samal adalah sebagai berikut : pada elevasi $1550 \mathrm{~m}$ dpl memiliki persentase luas sebesar 3,61 \%, $1275 \mathrm{~m}$ $\mathrm{dpl}=9,41 \%, 825 \mathrm{~m} \mathrm{dpl}=38,79 \%, 475 \mathrm{~m} \mathrm{dpl}=$ $71,58 \%$, dan $225 \mathrm{~m}$ dpl memiliki persentase luas sebesar $88,89 \%$.

\section{Gradien Sungai Utama}

Dari hasil analisis planimetris terhadap peta topografi DAS Wai Samal, maka didapatkan bahwa $\mathrm{h}_{85}=$ elevasi pada titik sejauh $85 \%$ dari outlet DAS adalah sebesar $125 \mathrm{~m}$; $\mathrm{h}_{10}=$ elevasi pada titik sejauh $10 \%$ dari outlet DAS adalah sebesar $12,5 \mathrm{~m} ; \mathrm{Lb}=$ panjang sungai utama adalah $35,30 \mathrm{~km}$ atau $35300 \mathrm{~m}$. Hasil perhitungan didapatkan bahwa gradien sungai utama DAS Wai Samal adalah sebesar 0,04. 


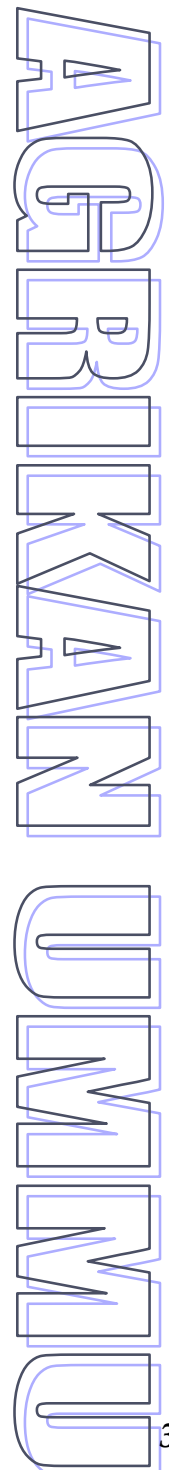

3.2. Karakteristik Hidrologi DAS

a. Limpasan Permukaan

Hasil perhitungan debit limpasan permukaan maksimum di DAS Wai Samal adalah sebesar $1435,50 \quad \mathrm{~m}^{3} /$ det. Ini menggambarkan limpasan permukaan saat mencapai puncak sehingga menyebabkan terjadinya banjir puncak di DAS ini. Sebaliknya hasil perhitungan debit limpasan permukaan minimum di DAS ini tidak mencapai nol, tetapi memiliki nilai tertentu yang selalu mengalir sebesar $17,101 \mathrm{~m}^{3} /$ det. Ini menggambarkan kondisi limpasan permukaan di DAS Wai Samal saat terjadinya musim kemarau.

Limpasan permukaan (overland flow) merupakan bagian kelebihan hujan (excess rainfall) yang mengalir di permukaan lahan pada saat terjadi hujan, apabila hujan berhenti maka tidak terjadi lagi limpasan permukaan. Koefisien limpasan permukaan adalah perbandingan antara bagian hujan yang menjadi limpasan permukaan dengan total hujan pada suatu kejadian hujan. Limpasan permukaan inilah yang menjadi tenaga penggerus/pengelupas lapisan tanah atas, pengangkut material tanah permukaan yang lepas atau yang dikenal dengan proses erosi permukaan oleh tenaga limpasan permukaan, yang kemudian membawanya ke dalam badanbadan air (sungai, rawa, danau, waduk, dan laut/lautan) membentuk banjir kiriman (banjir limpasan) menyumbang banjir di sungai serta membawa lumpur yang menyebabkan pendangkalan atau dikenal dengan proses sedimentasi.

b. Debit Maksimum (Q Max)

Pengukuran debit banjir maksimum (Qmaks) dapat dilakukan pada saat musim hujan dengan melihat tanda-tanda banjir puncak pada tepi penampang sungai atau menanyakan kepada penduduk setempat 
(lokal) atau dengan menggunakan metode Rasional.

Hasil perhitungan debit maksimum $(Q$ maks) di DAS Wai Samal menggunakan metode Rasional adalah sebagai berikut :

Diketahui luas DAS $=45777,36$ ha; koefisien $C=0,00278$; intensitas hujan adalah $11,28 \mathrm{~mm} /$ hari. $\mathrm{Q}$ maks $=\mathrm{CIA}=0,00278 \times 11,28$ $\mathrm{mm} /$ hari $\times 45777,36$ ha $=1435,50 \mathrm{~m}^{3} /$ det. Dari hasil tersebut, terlihat bahwa debit maksimum atau debit banjir puncak di DAS Wai Samal adalah sebesar $1435,50 \mathrm{~m}^{3} / \mathrm{det}$.

\section{c. Debit Minimum (Q Min)}

Pengukuran debit minimum dipilih dalam kondisi debit sungai paling kecil pada saat musim kemarau. Pada dasarnya debit

Tabel 5. Debit Minimum DAS Wai Samal

\begin{tabular}{rlrrr}
\hline No & \multicolumn{1}{c}{ Lokasi (Sub DAS) } & $\begin{array}{c}\text { V } \\
(\mathrm{m} / \mathrm{det})\end{array}$ & \multicolumn{1}{c}{$\begin{array}{c}\mathrm{A} \\
\left(\mathrm{m}^{2}\right)\end{array}$} & $\begin{array}{c}\text { Q Limpasan } \\
\left(\mathrm{m}^{3} / \mathrm{det}\right)\end{array}$ \\
\hline 1 & Jembatan Wai Samal & 0.45 & 17.71 & 7.920 \\
2 & Tengah sungai Wai Samal & 0.85 & 3.75 & 3.20 \\
3 & Bendungan Intek (W. Asih) & 0.44 & 140.63 & 61.35 \\
4 & Irigasi Primer Sungai W. Samal & 1.36 & 2.60 & 3.55 \\
5 & Sungai W. Musi & 0.26 & 2.00 & 0.52 \\
6 & Sungai W. Kobi & 0.96 & 27.05 & 26.07 \\
\hline \multicolumn{2}{|}{ Rataan } & & & 17.101 \\
\hline
\end{tabular}

Sumber : Hasil Penelitian dan Analisis, 2014

\section{d. Debit Rata-Rata (Qav)}

Merupakan rataan dari Debit Maksimum (Q maks) sebesar 1435,50 $\mathrm{m}^{3} /$ det dan Debit Minimum ( $Q \mathrm{~min}$ ) air sungai di DAS Wai Samal sebesar 17, $101 \mathrm{~m}^{3} / \mathrm{det}$ sehingga didapatkan hasil sebesar : $726,30 \mathrm{~m}^{3} /$ det.

Debit aliran rata-rata (Qav) dari suatu sungai merupakan besaran hidrologi yang penting sebagai indikator potensi DAS dalam menyimpan air hujan yang jatuh ke dalam lapisan akuifer untuk selanjutnya dikeluarkan secara pelan-pelan dalam bentuk mata air ataupun rembesan. Besarnya debit aliran ratarata setiap tahunnya tinggi menunjukkan bahwa wilayah DAS sebagai prosesor cukup berfungsi baik, hal ini menunjukkan karakteristik DAS atau kesehatan DAS terjaga.

e. Koefisien Regime Sungai (Qmax/Qmin)

Hasil analisis menunjukkan bahwa debit maksimum adalah $1435,50 \mathrm{~m}^{3} / \mathrm{det}$, sedangkan debit minimum rata-rata untuk seluruh DAS adalah sebesar 17,101 $\mathrm{m}^{3} / \mathrm{det}$, sehingga Koefisien Regime Sungai $=1435,50$ minimum suatu sungai tidak pernah sama dengan nol (Qmin tidak 0) karena sebelum air sungai itu mengalir hingga mulut sungai biasanya di bagian hulu DAS air sungai telah dimanfaatkan oleh penduduk petani untuk irigasi tradisional. Hasil pengukuran dari 6 titik outlet yang diukur debitnya pada DAS Wai Samal seperti disajikan dalam Tabel 4.10, menjelaskan bahwa Debit Minimum yang diukur pada musim kemarau adalah 17, 101 $\mathbf{m}^{3 / \text { det. }}$.

Perlu juga dijelaskan bahwa debit minimum pada lokasi penelitian bervariasi pada 6 titik outlet. Dalam menghitung debit air sungai perlu juga pengukuran lebar sungai dan ketinggian muka air sungai

$\mathrm{m}^{3} /$ det $/ 17,101 \mathrm{~m}^{3} /$ det $=83,94 \mathrm{~m}^{3} /$ det. Setelah dipadukan dengan kriteria, maka ternyata hasil menunjukkan bahwa Koefisien Regime Sungai $>50$, yang berarti bahwa lebih banyak kejadian banjir yang terjadi di DAS Wai Samal.

f. Koefisien Penyimpanan/Storage Sungai (Qmin/Qav)

Hasil analisis menunjukkan bahwa debit minimum rata-rata untuk seluruh DAS adalah sebesar $17,101 \mathrm{~m}^{3} / \mathrm{det}$, sedangkan debit rata-rata adalah $726.41 \mathrm{~m}^{3} /$ det, sehingga Koefisien Storage Sungai $=17,101 \mathrm{~m}^{3} / \mathrm{det} / 726.30 \mathrm{~m}^{3} / \mathrm{det}=$ 0,024. Setelah dipadukan dengan kriteria, maka ternyata Kofisien Storage Sungai DAS Wai Samal <50 yang berarti debit minimum (Qmin) yang terjadi justru semakin mendekati besarnya debit rata-rata atau dengan kata lain debit minimum pada musim kemarau masih cukup besar.

Parameter karakteristik hidrologi DAS yang diperoleh dari perbandingan antara debit minimum (Qmin) dan debit rata-rata (Qav) atau sering disingkat dengan parameter $\mathrm{Qmin} / \mathrm{Qav}$ 
merupakan indikator besaran hidrologi untuk menyatakan apakah DAS itu berfungsi sebagai prosesor untuk menyimpan air hujan yang jatuh sehingga dapat membentuk mata air yang permanen atau relatif permanen. Indikator parameter Qmin/Qav ini sebaliknya dengan parameter Qmaks/Qmin karena apabila nilai perbandingan ini kecil $(<50)$ yang berarti debit minimum (Qmin) yang terjadi harapannya justru semakin mendekati besarnya debit ratarata atau dengan kata lain debit minimum pada musim kemarau masih cukup besar.

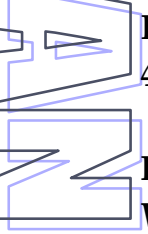

\section{KESIMPULAN DAN SARAN}

4.1. Kesimpulan

Berdasarkan hasil penelitian Analisis Karakteristik Morfometri dan Hidrologi DAS Wai Samal, maka dapat disimpulkan sebagai berikut :

1. Karakteristik Mofometri berupa Luas DAS $45.777,36 \mathrm{Ha}$ atau $457,77 \mathrm{~km}^{2}$ tergolong DAS kecil dengan bentuk DAS memanjang dan berbentuk dendritik. Terdapat 5 orde Jaringan Sungai dengan kelas kerapatan sebesar $1,91 \mathrm{~km} / \mathrm{km}^{2}$ tergolong sedang.

2. Karakteristik Hidrologi menunjukkan limpasan permukaan dan debit maksimum sebesar 1435,50 $\mathrm{m}^{3} /$ det buruk dan sering terjadi banjir, namun debit minimum sebesar 17, $101 \mathrm{~m}^{3} /$ det adalah baik, debit rata-rata sebesar $726,30 \mathrm{~m}^{3} /$ det adalah sangat baik. Koefisien Regime Sungai sebesar 83,94 $\mathrm{m}^{3 / d e t}$ adalah tergolong sedang, Koefisien Storage Sungai sebesar 0,024 adalah masih cukup besar.

4.2. Saran

Perlu ada penelitian lanjutan di DAS Wai Samal dalam hal Karakteristik Biogeofisik dan Karakteristik Sosekbud masyarakat dan kelembagaan DAS.

\section{DAFTAR PUSTAKA}

Direktur Jenderal Bina Pengelolaan Daerah Aliran Sungai dan Perhutanan Sosial : P 3/ V-SET/ 2013. Pedoman Identifikasi Karakteristik Daerah Aliran Sungai.

Gunawan T,2012. Reiview Pedmoan Penyusunan Karakteristik DAS. Makalah Pada Sosialisai PP. 73. Tentang Pengelolaan DAS. Manado 7 - 9 Maret 2012.

Kementrian Kehutanan Republik Indonesia. 2010. Rencana Teknis Rehabilitasi Hutan dan Lahan Daerah Aliran Sungai (DAS) - RTKRHL-DAS

Sinukaban, N., 2007. Peranan Konservasi Tanah dan Air Dalam Pengelolaan DAS. Bunga Rampai Konservasi Tanah Dan Air.

Talakua S.M., 2009. Pengaruh Penggunaan Lahan Terhadap kerusakan Tanah Karena Erosi Di Kecamatan Kairatu Kabupaten Seram Bagian Barat Propinsi Maluku. Disertasi Program Pascasarjana Universitas Padjadjaran Bandung. 